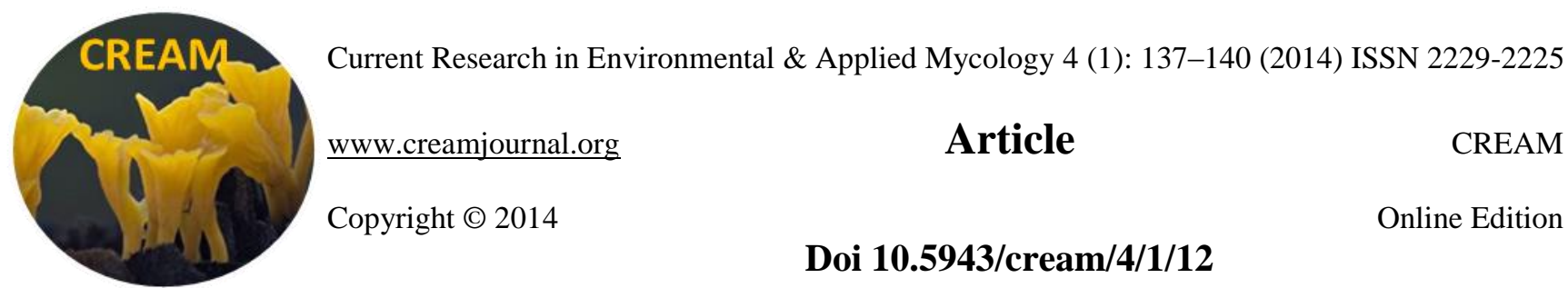

\title{
Immersaria and Koerberiella, two new generic records to India
}

\section{Pandit GS}

Agharkar Research Institute, G.G. Agarkar Road, Pune 411004 Email: gargee.pandit @ gmail.com

Pandit GS 2014 - Immersaria and Koerberiella, two new generic records to India. Current Research in Environmental \& Applied Mycology 4 (1): 137-140, Doi 10.5943/cream/4/1/12

\begin{abstract}
The crustose lichen genera Koerberiella and Immersaria were discovered from the NorthWestern ghats of India and represents new generic records for the lichen flora of the Indian continent. The genus Koerberiella is represented here by a sterile isidiate morphotype of $K$. wimmeriana from the rocky outcrops of Kas and Immersaria by a species closely related to $I$. olivacea from the Panchgani plateau.
\end{abstract}

Key words - lichen - outcrops - Porpidiaceae - taxonomy

\section{Introduction}

The Western Ghats is an imposing north-south hill range that forms the western edge of the Deccan plateau. The Western Ghats hilltops are characteristically flat tabletops or mesas. The toposheets of the region often mark these rocky plateaus as "rocky scrub" or "rocky waste" or simply as sheet rock. Owing to the scarcity of woody species or forest cover, the plateaus appear devoid of vegetation in the Remote Sensing images. Despite the fact that rock outcrop habitats form striking landscape elements throughout India and often have an immense cultural and religious importance, very few have been studied for their biodiversity (Aparna Watve 2013). This study is based on surveys and collection of lichens on the Kas and Panchgani plateaus in India. This article gives an account of two species in the genera Koerberiella Stein. and Immersaria Rambold \& Pietschm newly found in the Satara district, Maharashtra. Generic characters are given in Table 1.

In recent years, several crustose lichens with aspicilioid apothecia have been recognized as members of the family Porpidiaceae. This family is represented with twenty-one genera at the world level (http://zipcodezoo.com/Key/Fungi/Porpidiaceae_Family.asp) and, in India, it is represented by only one genus Porpidia Körb. and its three species and their varieties (Upreti \& Chatterjee 2002). Porpidiaceae family is mainly characterized by asci with a tube-like amyloid structure in the tholus and non septate, typically halonate ascospores. Hafellner (1984) established the family Porpidiaceae and designated Porpidia as its largest genus. Most members of the Porpidiaceae are lecideoid although a few are more or less aspicilioid or lecanoroid (Rambold et al. 1990). Lecanorine apothecia occur constantly in the lichen genus Koerberiella, which is the only true lecanorine member of the family Porpidiaceae (Hafellner 1984).

Molecular studies (Buschbom \& Barker 2006) indicates that Porpidia is not monophyletic as some smaller genera (Amygdalaria, Immersaria, Stenhammarella and Stephanocyclos) of the Porpidiaceae and probably also the genus Lecidea (Lecideaceae), are nested within it. (Li Bo et al. 2014). 
Koerberiella is represented by twenty six species and Immersaria is represented by seven species at the world level (www.indexfungorum.org) and in India they form the first generic records.

\section{Materials \& Methods}

The study is based on the collection made at Kas and Panchgani rocky outcrops, Satara district, Maharashtra. The specimens are deposited in the Ajrekar Mycological Herbarium (AMH). Sections of the thalli and ascomata were mounted in water, $10 \% \mathrm{KOH}(\mathrm{K})$, Lugol's solution (I), and lactophenol cotton blue (LPCB). All measurements were made on material mounted in water. Secondary products were identified by thin-layer chromatography using standards methods (Culberson \& Kristinsson 1970; Culberson 1972; White \& James 1985) with the solvent systems toluene-dioxane-acetictic acid (180:45:5) and toluene-ethyl acetate-formic aid (139:83:8). The plates were examined under UV light (365 nm).

\section{The Species}

Immersaria cf. olivacea Calatayud \& Rambold

Fig. 1 Lichenologist 30(3): 234 (1998).

Thallus crustose, saxicolous, areolate, whitish to off white, sometimes creamish, cracked, non sorediate, non isidiate, epruinose; hypothallus indistinct or not seen. Upper cortex hyaline, paraplectenchymatous; medulla with crystals. Lower cortex paraplectenchymatous. Ascomata black, apothecioid, flush with the thallus to immersed, 1-4 (-5) per areolate, up to $1 \mathrm{~cm}$ wide. Areoles up to $0.5 \mathrm{~mm}$ in diam. Disc shiny black, convex, epruinose, lecanorine, with margin epruinose, concolorous with the thallus. Proper exciple prosoplectenchymatous. Epithecium greenish, 12.5-20 $\mu \mathrm{m}$ tall, anastomosed and branched. Hymenium hyaline, 100-125 $\mu \mathrm{m}$ tall. Hypothecium hyaline, 100-125 $\mu \mathrm{m}$ tall. Asci 8-spored. Ascospores hyaline, 1-septate, 9-11 × 5-6 $\mu \mathrm{m}$.

Chemistry - Thallus UV-, atranorin, gyrophoric acid and traces of unknown substances present.

Remarks - The specimen from India resembles Immersaria olivacea in having 1-septate ascospores and an epihymenium greenish in colour, but differs from this species in the thallus colour (olivaceous in I. olivacea) and the chemistry: Immersaria olivacea either lacks lichen substances or has traces of stictic acid, whereas the specimen from India has atranorin, gyrophoric acid and traces of unknown compounds. Because I have only a single collection from the area and further collection could reveal variations in chemistry and thallus colour, I am here recording this species as Immersaria cf. olivacea. The studied specimen has been collected on exposed volcanic rocky outcrops in a disturbed habitat at an altitude of approximately $1200 \mathrm{~m}$. The specimen has been found growing on the East-facing side of the rock from Panchgani. However, this species is known from Spain at a low altitude not exceeding $700 \mathrm{~m}$.

The specimen from India is similar to Immersaria usbekica (Hertel) M. Barbero, Nav.-Ros. \& Cl. Roux and Immersaria cupreoatra (Nyl.) Calatayud \& Rambold an Eurasian species in having gyrophoric acid, but otherwise differs in many other characters (e.g., spore septation). (Calatayud \& Rambold 1998).

Specimen examined (AMH) - India, Maharashtra: Satara District, Panchgani plateau, 15.10.2013, about 1200 m elevation, 2013, G.S. Pandit, 13.67.

Koerberiella wimmeriana (Körber) B. Stein

Fig. 1B In Cohn, Krypt. Fl. Schlesien 2(2): 143 (1879).

Thallus crustose, saxicolous, greenish grey to bluish-green, isidiate, scars of the fallen isidia visible. Isidia globular initially, later cylindrical, 25-37.5 $\mu \mathrm{m}$ tall. Upper cortex reddish-brown, parenchymatous, (12.5) $-20-30 \mu \mathrm{m}$ tall. Algal layer more or less uniform, 37.5-50 $\mu \mathrm{m}$ thick, with dark green algae, unicellular, roundish, 5-7.5 $\mu \mathrm{m}$ in diameter. Medulla white, cellular, 25-30 $\mu \mathrm{m}$. 

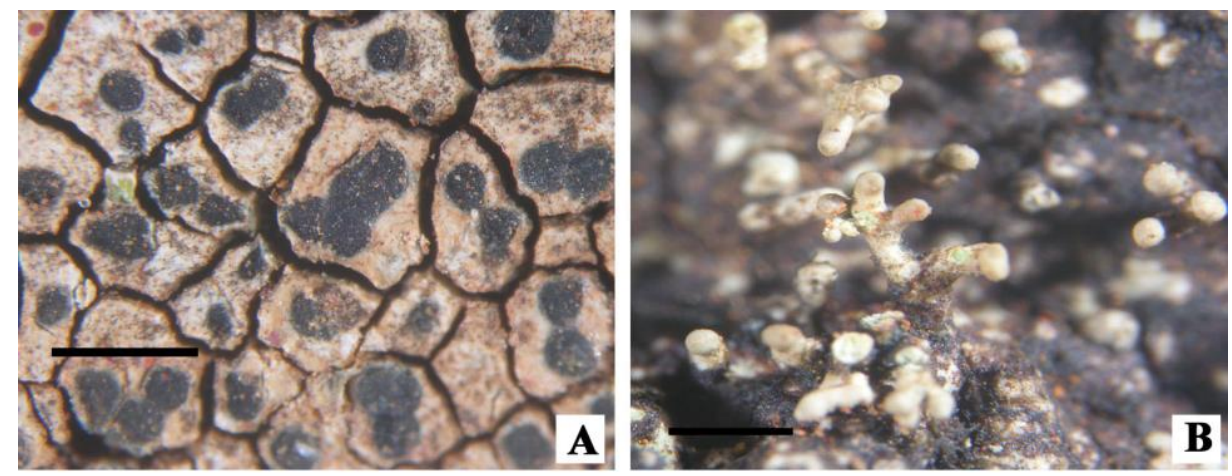

Fig.1 - Habitus. A. Immersaria olivacea; B. Koerberiella wimmeriana (AMH). Bars =1 mm.

Lower cortex dark reddish-brown, 25-37.5 (50) $\mu \mathrm{m}$ tall, sometimes rhizoid like structures seen centrally, bushy and dark chocolate colour, embedded in rock. Hypothallus black. Apothecia not seen.

Chemistry -Thallus UV- ; atranorin and an unknown greenish substance at Rf 4.

Remarks - The sterile morphotype is the most common form seen in Europe (Rambold et al. 1990). Koerberiella wimmeriana is the only isidiate taxon in the Porpidiaceae family. Greenish grey to bluish-green, isidiate patches were found on the more exposed somewhat disturbed parts of the same rock surface as well as in the crevices of the boulders. Indian specimens match with the photographs of (Sharnoff S (http://www.sharnoffphotos.com/lichensH/lichen_mysteries_11.html) and resemble the common European morph, with both the dispersed-areolate, verrucose to "isidioid" patches, and the more or less smooth rimose-areolate patches.

Found growing directly on the exposed rocky lateritic plateaus at an altitude of about 1227 $\mathrm{m}$ and in the disturbed area of the Kas plateau, where there is disturbance by tourism. It was also collected near the rock crevices at $17^{\circ} .72486^{\prime} \mathrm{N}$ to $73^{\circ} .82729^{\prime} \mathrm{E}$. A single collection was also made in the undisturbed area of the plateau.

Distribution - India (Maharashtra), North-America, Western Europe and Eastern Asia. Specimens examined (AMH) - India, Maharashtra: Satara Disrict, Kas plateau, undisturbed area, about 1200 m elevation, 2013, G.S. Pandit \& S. Gaikwad, 13.02; disturbed area, C1L3, 2013, G.S. Pandit \& S. Gaikwad, 13.18; disturbed area, in crevices, $17^{\circ} .72486^{\prime} \mathrm{N}-73^{\circ} .82729^{\prime} \mathrm{E}$, G.S. Pandit \& S. Gaikwad, 13.19; disturbed C area, G.S. Pandit \& S. Gaikwad 13.23, 13.24.

Table 1 Characters of Immersaria and Koerberiella

\begin{tabular}{|c|c|c|}
\hline Characters & Immersaria Rambold \& Pietschm & Koerberiella B. Stein \\
\hline Thallus & $\begin{array}{l}\text { Thallus brown, areoles with a flat to concave } \\
\text { surface. }\end{array}$ & $\begin{array}{l}\text { Thallus crustose, areolate, mostly } \\
\text { isidiate, with coccoid trebouxioid } \\
\text { green algae, and containing para- } \\
\text { depsides of the orcinol-type. }\end{array}$ \\
\hline Apothecia & $\begin{array}{l}\text { Apothecia, immersed with a more or less } \\
\text { strongly reduced proper margin and with a } \\
\text { greenish-blackish pigmented parathecial crown, } \\
\text { which is mostly separated by a fissure from the } \\
\text { areole from which it originates. Exciple } \\
\text { lecanorine, prosoplectenchymatous. Hymenium } \\
\text { hyaline. Hypothecium hyaline. }\end{array}$ & $\begin{array}{l}\text { Apothecia sessile, roundish, with } \\
\text { lecanorine margin. Disc pale red- } \\
\text { brown to dark brown. Ectal } \\
\text { excipulum } \pm \text { pseudoparenchymatous, } \\
\text { medullary zone of the excipulum } \\
\text { partly containing algal cells. } \\
\text { Hymenium colourless, I + (bluish) } \\
\text { brown and I conc. + bluish brown to } \\
\text { orange. Hypothecium colourless } \\
\text { (partly with brownish to dark brown } \\
\text { pigment towards the subhypothecial } \\
\text { medulla). }\end{array}$ \\
\hline Asci & Porpidia-type, non-amyloid. & $\begin{array}{l}\text { Asci with amyloid tub-like structure in } \\
\text { the tholus. }\end{array}$ \\
\hline Ascospores & Ascospores hyaline, simple to 1 -septate. & Ascospores hyaline, simple, halonate. \\
\hline
\end{tabular}




\section{Acknowledgements}

The author is grateful to the Department of Science and Technology-SERB, SB/FT/LS187/2012 New Delhi for the financial support and to the Director of the Agharkar Research Institute Pune for providing laboratory facilities. Last but not the least I also thank the reviewers for their valuable suggestions.

\section{References}

Buschbom J, Barker D. 2006 - Evolutionary history of vegetative reproduction in Porpidia s. 1. (lichen-forming Ascomycota). Systematic Biology 55, 471-484.

Calatayud V, Rambold G. 1998 - Two new species of the lichen genus Immersaria (Porpidiaceae). Lichenologist 30(3), 231-244.

Culberson CF. 1972 - Improved conditions and new data for the thin layer chromatographic method. Journal of Chromatography 72, 113-125.

Culberson CF, Kristinsson H. 1970 - A standardized method for the identification of lichen products. Journal of Chromatography 46, 85-93.

Hafellner H. 1984 - Über saxicole, lecideoide Flechten der Subantarktis. In: Beiträge zur Lichenologie, Festschrift J. Poelt (H. Hertel \& F. Oberwinkler, eds), Beihefte zur Nova Hedwigia 79, 399-499.

Li Bo, Jia F, Shu-Lian X. 2014. - Relationships between the algal partners and the growth of lichen forming fungus Porpidia crustulata. Symbiosis Published online 6 March 2014. DOI 10.1007/s13199-014-0275-1

Rambold G, Hertel H, Triebel D. 1990 - Koerberiella wimmeriana (Lecanorales, Popidiaceae) and its lichenicolous fungi. Lichenologist 22, 225-240.

Sharnoff Stephan 2014. - http://www.sharnoffphotos.com/lichensH/lichen_mysteries_11.html (accessed 12 March 2014)

Upreti DK, Chatterjee S. 2002 - The lichen genus Porpidia in India. Geophytology 30(1\&2), 99101.

Watve A. 2013 - Status review of Rocky plateaus in the northern Western Ghats and Konkan region of Maharashtra, India with recommendations for conservation and management. Journal of Threatened Taxa 5(5), 3935-3962.

White FJ, James PW. 1985 - A new guide to microchemical techniques for the identification of lichen substances. British Lichen Society Bulletin 57 (Suppl.), 1-41.

www.indexfungorum.org -2014.

http://zipcodezoo.com - 2014. (accessed 12 March 2014). 